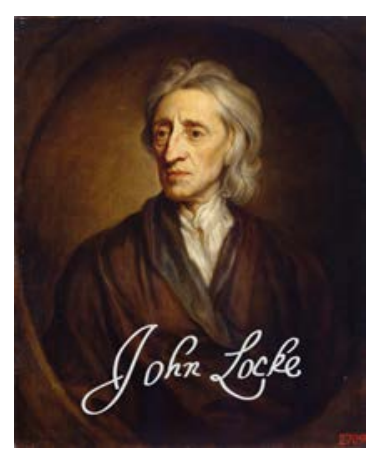

\title{
LOCKE STUDIES
}

Vol. 19

https://doi.org/10.5206/ls.2019.8433 | ISSN: 2561-925X

Submitted: 20 OCTOBER 2019

Revised: 03 DECEMBER 2019

Published online: 20 DECEMBER 2019

For more information, see this article's homepage.

(C) 2019. Michael Jacovides

\section{Replies to My Critics}

\section{MICHAEL JACOVIDES (PURDUE UNIVERSITY)}

\begin{abstract}
:
This is a revised version of a paper presented at the APA Eastern Division's 115th annual meeting in New York on Monday J anuary 07, 2019. It was presented at session $2 O$ Author Meets Critics: Michael Jacovides, Locke's Image of the World. The session chair was Antonia LoLordo (University of Virginia), the critics were Robert Pasnau (University of Colorado Boulder) and Kathryn Tabb (Bard College), and the author was Michael J acovides (Purdue University).
\end{abstract}

Keywords: J ohn Locke, corpuscularianism, conceivability, substance, real essence, perception

Locke Studies is published by The John Locke Society.

This is an open access article published under the terms of the Creative Commons AttributionNonCommercial-ShareAlike 4.0 International license, which permits use, distribution and reproduction in any medium, provided the original work is properly cited and shared under the original license. 
I'm very pleased with Robert Pasnau's and Kathryn Tabb's knowledgeable and insightful comments on Locke's Image of the World. The disagreements are gratifyingly small, which is good and bad. The good part is that it's nice to be agreed with. The bad part is that fussing over small differences might leave the audience in the dark about the point of the book and about what it is that we're agreeing about. I'll structure my reply around the structure of my book, which will probably clarify things.

The book started as a dissertation on Locke on primary and secondary qualities. I published parts of it, and I figured I would put the parts back together and publish it as a book. For a very long time, however, I was just moving pieces around, and the whole seemed like less than the sum of its parts. I eventually wrote a paper describing the rise and fall of Locke's view that we see a two-dimensional array as an aspect shift brought about by background discoveries. This Kuhnian thought made me think that I could unify my book as an exercise in Kuhnian history of philosophy. I wanted to justify not just the commonplace that we need background knowledge to understand texts, but also two more controversial doctrines: first, that scientific opinions can shape perceptions and, second, that they can determine the boundaries of the conceivable. This snapped the book into focus and gave me a chance to talk about something bigger than what Locke meant by this or that phrase. I state my goals in the first chapter.

After committing to my Kuhnian project, I thought I should learn more about Locke's early work in physiology and his later collaboration with Thomas Sydenham. The conclusions I draw in Chapter 2 are that Locke doesn't limit himself to corpuscularian concepts in his work on respiration and disease in the early 1660s, that his work with Sydenham leads both of them to skepticism about explanatory hypotheses in medicine, and that this skepticism helps explain Locke's pessimism about finding definite explanatory hypotheses in natural philosophy.

Tabb thinks I should be bolder and say not just that he doubted the truth and utility of contemporary biomedical hypotheses but that he thought "it was just unthinkable that the clinical mission could extend to what we might now think of as biomedical research,"1 at least when he's working as a doctor. As I read Locke's medical writings after 1666, he thinks that hypotheses and anatomy aren't useful for non-surgical medicine, but he never goes so far as to say or imply that it's inconceivable that they might be. I think Tabb takes his skepticism to be so mysterious as to require a deep explanation. I, on the other hand, think of it as an accurate reflection of the contemporary state of medicine. She knows more about the history of medicine than I do and her thought is certainly consistent with the spirit of my book, but I don't think the texts that she cites suffice to justify it. Put me down as interested but not yet convinced.

Locke explicitly defends corpuscularianism on the basis of the inconceivability of its alternatives, which is the subject of Chapter 3 . When he rejects action at a distance, he does so because he was in the grip of the best scientific theories of the day. When he accepts action at a distance, he likewise does so for good reasons conveyed to him by Isaac Newton. The puzzle in his treatment of the inconceivability of action at a distance in the fourth edition is that he thinks that inconceivability has some epistemic weight (and thus it justifies believing in imperceptible corpuscles that stimulate ideas of light, odor, and

${ }^{1}$ Kathryn Tabb, "Response to Locke's Image of the World" (paper read at the APA Eastern Division's 115th annual meeting, New York, J anuary 07, 2019). Revised version published in Locke Studies 19 (2019): 5, https:// doi.org/ 10.5206/ ls.2019.8431. 
sound) but it isn't a demonstration (and thus it's compatible with a belief that gravity works at a distance).

I concluded that the best way to solve this puzzle is to acknowledge a third sort of conceivability in light of the shifting attitudes toward action at a distance during this time as told in histories by Alexandre Koyré 2 and I. Bernard Cohen. ${ }^{3}$ Locke grew up adhering to a corpuscularianism framework, and that framework made alternatives seem inconceivable. Corpuscularianism was the best justified theory of the time, and the inconceivability that Locke attaches to its alternatives borrows some of that justification. Later in life, he is convinced by Newton that gravity works at a distance, and thus decides that something that he considers inconceivable is true. This revelation doesn't lead him to abandon every last bit of corpuscularianism. Reasonably enough, he retains a role for imperceptibly small bodies in his accounts on smell, hearing, and sight. As I understand it, the justificatory power of this sort of inconceivability is parasitic on the explanatory power of the underlying theory. If you are in the grip of a theory, and that theory is a good one, then your inability to conceive of alternatives has some epistemic value.

It seems to me that my differences with Pasnau on this subject are rather subtle. I say that Locke's adoption of an explanatory hypothesis constrained the bounds of what he could conceive of through a Kuhnian psychological mechanism. Pasnau thinks that this lets in too much daylight between explanation and conceivability and that, in the relevant texts "we should be hesitant to pull these things apart."4 According to Pasnau, I guess, Locke just means the only way which we can explain when he writes "the only way which we can conceive" in the Fourth Edition of Essay II.viii.11. Pasnau thinks his interpretation of Locke on conceivability gives Locke's arguments gives "more power" than I allow, 5 but I think that we attribute an equal amount of power to them, or, at any rate, we take them to rest upon the same basis. When Locke uses conceivability considerations against an position and he doesn't think that the position is provably, demonstrably false, I say that the epistemic force of his arguments depends on the explanatory strength of an underlying hypothesis, in this case, corpuscularianism.

Pasnau says that my view is "philosophically interesting but exegetically implausible," 6 which is in the ballpark of what I was aiming for. I do appeal to a text where Locke says that opinions taken on trust can harden so that they're taken to be self-

2 Alexandre Koyré, "The Significance of the Newtonian Synthesis," in Newtonian Studies (Chicago: University of Chicago Press, 1965).

3 I. Bernard Cohen, Franklin and Newton: An Inquiry into Speculative Newtonian Experimental Science and Franklin's Work in Electricity as an Example Thereof (Philadelphia: The American Philosophical Society, 1956), 243-99.

4 Robert Pasnau, "The Conceivability of Locke's Image of the World: Some Thoughts on Jacovides" (paper read at the APA Eastern Division's 115th annual meeting, New York, January 07, 2019). Revised version published in Locke Studies 19 (2019): 5, https:// doi.org/ 10.5206/ ls.2019.8432.

${ }^{5}$ Pasnau, “Conceivability,” 4.

6 Pasnau, "Conceivability," 6. 
evident, ${ }^{7}$ and I do suggest that he could envision a similar hardening process occurring with justified, probable beliefs. Still, in my discussion of the third sort of inconceivability I was treating Locke less as an epistemologist and more as an object of study for epistemologists. Whether the inference fits into his official epistemology or not, Locke treats the inconceivability of action at a distance as defeasible evidence against action at a distance, and, speaking in my own voice, I think that that inference is justifiable, comprehensible, and interesting.

Pasnau says that on his approach Locke's appeals to conceivability are "more objectively grounded" 8 than they are on mine. I don't think this judgment rests on an exegetical disagreement about what Locke means by some sentence or term, but rather on our disagreement about whether what counts as a good explanation changes over time. In particular, we disagree about whether "pretty much everyone throughout the history of philosophy and physics, up to this day" rejects the conceivability of action at a distance. ${ }^{9}$ In the book I cite Galen, William of Ockham, J an Baptist Van Helmont, Robert Fludd, and Roger Cotes, but I guess these could be thought of quirky exceptions. The heyday of action at a distance was the eighteenth and nineteenth centuries. In the 1846 edition of Mill's System of Logic, he quotes Newton's letter to Bentley in which Newton says it's inconceivable that brute matter can act at a distance without mediation by something else. Mill declares that the "passage should be hung up in the cabinet of every man of science who is ever tempted to pronounce a fact impossible because it appears to him inconceivable." 10 He reports on attitudes in the nineteenth century: "No one now feels any difficulty in conceiving gravity to be, as much as any other property is, "innate, inherent, and essential to matter," nor finds the comprehension of it facilitated in the smallest degree by the supposition of an ether; nor thinks it at all incredible that the celestial bodies can and do act where they, in actual bodily presence, are not." "11 If Mill can be trusted, no one in the middle of the nineteenth century thinks action at a distance is inconceivable. I don't think that my view that conceivability changes with paradigms entails any skeptical or subjectivist consequences for science or its progress, since I think that paradigms of explanation generally have improved over time.

I don't in principle have any objection to having a fourth notion of conceivability, that of explanatory power. As Pasnau suspects, ${ }^{12}$ I would rather call it explanatory power, but I don't want to fight over words. (If we do decide to stipulate that what lacks explanatory power is inconceivable, then I can agree with Tabb that Locke thinks that medical

7 See John Locke, An Essay concerning Human Understanding, ed. Peter H. Nidditch (Oxford: Clarendon Press, 1975), IV.xvi.4, 660-61.

8 Pasnau, “Conceivability," 2.

9 Pasnau, “Conceivability,” 6.

${ }^{10} \mathrm{~J}$ ohn Stuart Mill, A System of Logic, Ratiocinative and Inductive, 2nd ed., 2 vols. (London: J ohn W. Parker, 1846), 1:461.

${ }^{11}$ Mill, System of Logic, 1:461- 62.

12 Pasnau, “Conceivability," 5. 
hypotheses are inconceivable in this sense.) The lack of comparative explanatory power is what ultimately justifies our rejection of rivals to our best scientific theory.

I make some disparaging remarks about Locke's theory of ideas, suggesting that he elevates corpuscularian intuitions and a hostility toward hypotheses into a theory of conception that wrongly rules out our being able to conceive of corporeal interactions beyond impulse. This is an odd source of psychological incapacity, one that empiricist philosophers in particular are susceptible to. They form a false theory about the boundaries of thought, internalize their own theory, and, as a consequence, become unable to conceive of thoughts beyond those boundaries.

Tabb makes the interesting suggestion that Locke wouldn't mind if his theory of ideas draws the lines between the conceivable and the inconceivable too narrowly, since the cost of error "is not as high" as the costs associated with "enthusiasm and delusion that comes with a credulous attitude toward the existence of speculative entities."13 I think Locke would have defended his theory of ideas as true and useful in fighting various intellectual and religious corruptions, but there isn't much room for false but useful philosophy on his worldview. His official soteriology is that everyone who believes that J esus is the Messiah and sincerely tries to follow revealed law is saved, ${ }^{14}$ which would let in some Catholics and seventeenth-century dissenters. His unofficial view sometimes seems to be that God will save all honest enquirers into theological truth. ${ }^{15}$ Either way, I don't think he would be happy with an unjustified theory of ideas as a bulwark against enthusiasm and superstition.

Chapter 4 is about corporeal substance. Pasnau and I agree that Lockean substances are ordinary objects in which qualities inhere. We disagree about what we would learn if we had a clear idea of substance. I take Locke's transition from Section 3 to Section 4 in his chapter on substance (II.xxiii) to show that he thinks of puzzles at the foundations of corporeal substance and thinking substance as illustrative instances of the obscurity of our idea of substance in general. Pasnau cites Essay II.xxiii.15 where Locke says that our idea of matter is composed of our idea of coherent solid parts, the idea of the ability to be moved, and an idea of substance. This a good text for my reading. In context, the point of the passage is that our idea of substance is equally obscure in our idea of matter as it is in our idea of immaterial spirit, because there are similar explanatory difficulties associated with each. J ust as we can't explain how bodies cohere or push each other, we can't explain how spirits think or move bodies. Locke believes that our core conception of matter is cohesion, the capacity to be pushed, and an obscure idea of substance that represents a deeper, unknown explanation of cohesion and impulse.

I think that Pasnau and I disagree about the importance of cohesion in Locke's metaphysics. Here I would distinguish two levels. At one level is a foundational puzzle about "the union, or consolidation of parts of those Bonds, or of that Cement, or of the

13 Tabb, “Response," 12.

14 J ohn Locke, The Reasonableness of Christianity, ed. J ohn C. Higgins-Biddle (Oxford: Clarendon Press, 1999), ch. 11, 108- 21.

${ }^{15}$ Locke, Essay, IV.xiv.2, 652; IV.xvii.24, 688; Reasonableness, 139-41. 
least Particle of Matter that exists"16 that a clear idea of corporeal substance would explain. Above that is the presumably corpuscularian account of how these particular particles come to cohere into macroscopic solids. For Locke, this joining suffices to produce a body: "if two or more Atoms be joined together into the same Mass . . . the Mass, consisting of the same Atoms, must be the same Mass, or the same Body, let the parts be never so differently jumbled" ${ }^{17}$ Cohering atoms constitute a body, and bodies are extended, solid substances. ${ }^{18}$ Pasnau's assertion that a stick tied to a stonecan't constitute a substance is an Aristotelian thought, not a corpuscularian one. 19

In Chapter 5, I give an account of how primary qualities inhere in bodies. I take the real essence of a body to be the determinations of the primary qualities of a body, and, thus understood, that the real essence inheres in its body. Pasnau wants me to stipulate that the real essence isn't the determination of all the primary qualities.

Sometimes Locke writes as if real essences are relative to a sort ${ }^{20}$ and sometimes he writes as if they aren't. ${ }^{21}$ Insofar as they are relative to a sort, I think that only the primary qualities that explain the features in that sort should count. Insofar as they are independent of a sort, all of the determinate primary qualities of a body should count. I think the sort-independent conception of real essence is metaphysically more basic, since it doesn't require appealing to a conceptual sort. A clear idea of corporeal substance would tell us why bodies cohere and how they transfer motion, a clear idea of the sortal real essence of a body would tell us the determinate primary qualities that explain why the body falls under the sortal, and a clear idea of the sort-independent real essence would tell us all the determinate primary qualities of a body.

For Pasnau, the key to having a clear idea of substance is to have a clear idea of its real essence. ${ }^{22}$ I want to preserve the Lockean distinction between ignorance of real essence and ignorance of substance. As Seth Pringle-Pattison observes, ${ }^{23}$ Locke implies that ignorance of substance is something "besides" ignorance of real essence. ${ }^{24}$ Locke also implies that the relation between a clear idea of substance and "solid extended parts" is something like the explanatory relation between solid extended parts and "colour or

16 Essay, II.xxiii.26, 310.

${ }^{17}$ Essay, II.xxvii.3, 330.

18 Essay, II.xxiii.22, 307- 8.

19 Pasnau, “Conceivability,” 8.

20 See Locke, Essay, III.vi.2, 439; III.vi.6, 442; III.x.17- 19, 499- 501.

${ }^{21}$ See Locke, Essay, II.xxxi.6, 379- 80; III.iii.15, 417; III.vi.19, 449. For discussion, see J an-ErikJ ones, "Locke on Real Essence," in Stanford Encyclopedia of Philosophy, revised September 4, 2018. https:// plato.stanford.edu/ entries/real-essence/.

22 Pasnau, "Conceivability," 9.

${ }^{23}$ Seth Pringle-Pattison, in An Essay concerning Human Understanding, by J ohn Locke, ed. Seth Pringle-Pattison (Oxford: Clarendon Press, 1924), $233 n 1$.

${ }^{24}$ Locke, Essay, II.xxxi.13, 383. 
weight." 25 The explanatory hierarchy here is that a clear idea of corporeal substance would explain the cohesion of solid parts. Anything that has coherent solid parts will have a determinate texture, and that texture will explain the secondary and tertiary qualities of the body.

Pasnau worries that if we say that a real essence is constituted by primary qualities that inhere in the substance, then that will lead us to the bad view that Locke thinks that substances have no qualities. ${ }^{26}$ I don't understand this inference at all. If the real essences of corporeal substances are primary qualities, and primary qualities inhere in substances, then every corporeal substance with a real essence will have qualities, at the very least the primary qualities that constitute its essence.

In chapter 6 I discuss Locke's version of the mind-body problem and the theological details of his solution to that problem. He thinks that there are two ways that God might intervene to produce thought and sensation: first, in the Cartesian way, by attaching a soul to a body and, second, through superaddition, by making it the case that mental properties inhere in a physical substratum. Pasnau argue ${ }^{27}$ that a passage in the Second Reply to Stillingfleet reveals that Locke thinks sensation can arise without divine intervention. I think the rhetorical point of the passage is that Locke assumes that Stillingfleet believes that God adds sensation to elephants without giving them immaterial souls. And so (and this is the point of the next paragraph), ${ }^{28}$ there's no logical or metaphysical bar to God superadding thought, reason, or volition to human brains. As Pasnau suggests, I think that God's intervention occurs at the tail end of perceptual processes and that up to that point, it works naturally through corpuscles knocking into each other.

In Chapter 7 I give my account of why Locke thinks we see a two-dimensional array. Tabb's remarks are mostly sympathetic, but I disagree with two of her comments: one about a view that she attributes to me and another about a view that she attributes to Locke. According to her, I argue "that seeing objects two-dimensionally in this way is not something that Locke would have had to have studied; like most of his contemporaries, he did not think objects are immediately perceived as having depth."29 This isn't something that I argue and it's contrary to the spirit of what I want to say. I think Locke is the first to argue that visual perception produces two-dimensional array of ideas in us. In an important paper, Gary Hatfield and William Epstein give plausible reasons for attributing a view like that to Descartes, ${ }^{30}$ but Descartes isn't explicit on the point, and I

${ }^{25}$ Locke, Essay, II.xxiii.2, 295- 96.

${ }^{26}$ Pasnau, “Conceivability,” 10.

${ }_{27}$ Pasnau, "Conceivability," 12. There, Pasnau is referring to: J ohn Locke, Mr. Locke's Reply to the Bishop of Worchester's Answer to his Second Letter, in The Works of J ohn Locke (London, 1823), 4:4601.

${ }^{28}$ Locke, Works, 4:461.

29 Tabb, “Response," 7.

30 Gary C. Hatfield and William Epstein, "The Sensory Core and the Medieval Foundations of Early Modern Perceptual Theory," Isis 70 (1979): 375- 78. 
don't think that most commentators have followed their interpretation. Descartes does clearly expound Kepler's discovery of the retinal image in the fifth discourse of the Optics, he does compare the retinal image to a painting ("peinture") produced in the manner of perspective painting, ${ }^{31}$ and he does invent the framework of ideas as modes of the mind. Still, Locke is the first to explicitly assert that sight presents us ideas in a variously colored plane.

Because Locke is at the beginning of (or at least close to the beginning of) the tradition of thinking that sight presents us with a two-dimensional array of ideas, he could not have picked it up in a ready-made package from his contemporaries. Instead, I argue, he came to his conclusion through theoretical considerations connected with the discovery of the retinal image and the perfection of realistic painting. Because it's possible to see what lies before us as either a collection of three-dimensional objects or, at least for a short time, as a two-dimensional array of color patches, these theoretical considerations had traction, and it came to seem obvious to Locke that what we see is a two-dimensional array. Once Locke's Essay was widely disseminated and accepted, his successors could inherit the doctrine as the standard view, but not before.

Our second disagreement is about what Locke actually believes. According to Tabb, I don't think that Locke is "insisting that we actually see color patches. He's rather saying that the fact that we usually do not is because of the power of habituation." 32 I like Tabb's suggestion and I don't like it. I like it because I personally don't think that we usually see a two-dimensional array. I don't like it because I don't think it's compatible with what Locke says. For example, he says that Malebranche makes a mistake when he writes that we see the sides of cubes as equal, ${ }^{33}$ and he wouldn't say that if Tabb's reading were right.

Still, there is an interpretive puzzle about saying Locke thinks that we all see twodimensional arrays but only some of us realize that fact. Tabb expresses this by saying that Locke is constrained by the principle "that we are conscious of all our ideas." 34 If Locke is committed to that, then, we might think, he's committed to thinking that everyone knows that we see a two-dimensional array. But he doesn't think that everyone knows that, and he seems proud of his insight and originality. Let me begin by distinguishing incorrigibility about ideas (all of our judgments about our ideas are true) from the unavoidability of true judgments about our ideas (if we have an idea that has a

31 René Descartes, Oeuvres de Descartes, 11 vols., ed. Charles Adam and Paul Tannery (Paris: J . Vrin, 1996), 6:123- 24; Discourse on Method, Optics, Geometry, and Meteorology, revised edition, trans. Paul J . Olscamp (Indianapolis: Hackett Publishing, 2001), 96-97. See also Celia Wolf-Devine, "Descartes on Visual Spatial Perception," in Descartes' Natural Philosophy, eds. Stephen Gaukroger, J ohn Schuster, and J ohn Sutton (New York: Routledge, 2000), 507.

32 Tabb, “Response," 10.

33 See J ohn Locke, An Examination of P. Malebranche's Opinion of Seeing All Things in God, in Works, 9:218. The reference in Malebranche is to Nicolas Malebranche, Oeuvres complètes de Malebranche, 20 vols., ed. André Robinet (Paris: J . Vrin, 1958- 84), 1:96- 97; The Search After Truth, trans. and ed. Thomas M. Lennon and Paul J. Olscamp (Cambridge: Cambridge University Press, 1997), 1.7, 33- 36.

34 Tabb, "Response," 8. 
feature F, we unavoidably judge that it is F.) I think that Locke is committed to the incorrigibility about ideas 35 but not to the unavoidability of judgments about them.

He does say that it is "near a Contradiction, to say, that there are Truths imprinted on the Soul, which it perceives or understands not" 36 and that ideas "cease to be any thing, when there is no perception of them," 37 but neither of those claims imply that every sensory idea is accompanied by a judgment that the idea is present. Indeed, as Nicholas J olley has argued, ${ }^{38}$ such a view would lead to paradox. Locke envisions oysters and cockles as having "some small dull Perception."39 Are we supposed to imagine that such perceptions are accompanied by judgments and that those judgments have metajudgments and so on to infinity? Locke thinks that our inattentiveness to our ideas of reflection explains why they aren't stored in memory until later in children's development. Though the "ideas of the Operations of their own Minds . . . pass there continually; yet like floating Visions, they make not deep Impressions enough, to leave in the Mind clear distinct lasting Ideas, till the Understanding turns inward upon it self, reflects on its own Operations, and makes them the Object of its own Contemplation." 40 Most of the time, our ideas of reflection aren't objects of contemplation. In another passage that Tabb quotes, ${ }^{41}$ Locke says that when the mind isn't paying attention, "it barely observes" some ideas and that "at other times, it lets them pass almost quite unregarded." 42 The "almost" and "barely" are intentional there. Ideas are for Locke the objects of perception and thought. They can't be entirely unnoticed by the mind in all its faculties. Once you distinguish between perception and judgment, however, ideas can be the object of perception without being the object of judgment. I think Locke thinks that the two-dimensional ideas presented to us in sight are like that. They pass through the mind continually, but they don't make an impression in judgment or memory until the understanding makes them objects of contemplation. Such is the power of habit that it can keep us from noticing what's going on right on top of our noses.

In Chapter 8, I say what I have to say about Locke on resemblance. Pasnau wants to know why, on my reading of Locke, does he think that successful, explanatory mental representation is through resemblance. Isn't this Aristotelianism and incompatible with my picture of a series of corpuscles knocking into each other with divine intervention at

35 Locke, Essay, II.xxix.5, 364; IV.iii.8, 543- 44.

36 Essay, I.ii.5, 49.

${ }^{37}$ Essay, II.x.2, 150.

38 Nicholas J olley, Locke's Touchy Subjects: Materialism and Immortality (Oxford: Oxford University Press, 2015), 38- 41.

${ }^{39}$ Locke, Essay, II.ix.14, 148.

40 Essay, II.i.8, 107.

${ }^{41}$ Tabb, “Response,” 10.

42 Essay, II.xix.3, 228. 
the end? I don't there's an incompatibility here, but I think I see what motivates the thought.

Locke's assumption that the ideas that represent qualities in a true explanatory theory resemble those qualities is a fragment of cognitive psychology from his predecessors, not just Scholastic Aristotelians but also Descartes. No philosopher, no matter how original and no matter how hostile to what came before, can avoid borrowing at least some conceptual fragments from previous systems.

There was always something attractive and something repulsive about the doctrine that representation is resemblance in the best-case scenario. There is, as Pasnau notes, ${ }^{43}$ the simile of the wax and the seal, and this can seem like an attractive model to philosophers of more than one stripe. Moreover, cast images including reflections show us how nature produces simulacra. One obvious way to make sense of our thoughts of distant, absent objects is through local representations, and resemblances would carry information of resembled external objects. Given the right background assumptions, mental images available to introspection might literally resemble external figures. On the other hand, if one isn't careful, thinking that all successful representation is through resemblance will lead to absurdities, like concrete blocks in the head or becoming the world's greatest cellist by thinking about it. This tension is present from the first book of De anima. Aristotle criticizes Anaxagoras for denying that representation is through resemblance but not coming up with an alternative account. ${ }^{44} \mathrm{He}$ also criticizes Empedocles's account of representation through resembling elements, since Empedocles doesn't give us an account of how composites such as man or stone are going to be represented. ${ }^{45}$ Aristotle evidently solved this problem to his satisfaction, ${ }^{46}$ and the later tradition embedded his account inside an optics, a metaphysics, and a physiology that softened the difficulties of thinking that representation is through resemblance.

Berkeley scholars sometimes wonder why he thought that an idea can only resemble another idea. I think it's better to ask why no one said so before Berkeley. The doctrine that ideas resemble mind-independent bodies is inherently problematic, but for a long time these difficulties were papered over with attractive optical, physiological, and cognitive doctrines. By Locke's day, that synthesis had begun to come undone, and he took a half-step out of thinking that representation was through resemblance. Berkeley is born late enough that the Scholastic theory of perception no longer provided intuitive support for thinking that ideas could resemble things that weren't ideas, and for him it was obvious that an idea can resemble nothing other than an idea.

In theninth chapter I give a sympathetic account of Locke's treatment of the semantics of secondary quality judgments. In the tenth chapter, I sum things up.

43 Pasnau, “Conceivability,” 12.

44 Aristotle, "On the Soul," in The Complete Works of Aristotle: The Revised Oxford Translation, ed. J onathan Barnes (Princeton University Press, 1984), 405b19- 23, 1:646.

45 Aristotle, "On the Soul," 409b29-410a11, 1:653.

46 Victor Caston gives a comic and scholarly taxonomy of interpretations of Aristotle on resemblance in "The Spirit and the Letter: Aristotle on Perception," in Metaphysics, Soul, and Ethics in Ancient Thought: Themes from the Work of Richard Sorabji, ed. Ricardo Salles (Oxford: Clarendon Press, 2005), 245- 320. 
Tabb asks ${ }^{47}$ what Locke would have thought of the book, which is not a question that I ever considered. I did put some effort into thinking about how Locke might conceptualize my "third sort" of conceivability, and Tabb is right to say that his diagnosis of the belief in innate principles is relevant here and elsewhere in my book. Since Locke thinks that the quantity and quality of sensory ideas can depend on attention, I suspect that he would open to thinking that their character might depend on our theoretical expectations. Locke and I share an interest in epistemic norms, a tolerance for human weakness in living up to those norms, and a deference to the views of the best natural scientists of the day. Insofar as my book exemplifies those attitudes, he might have liked it. I did spend my time thinking about a dead philosopher in a way that Locke recommended against, but his ghost still might be flattered by the attention.

But I didn't write it for him. The constituent parts were attempts to solve interpretive puzzles surrounding certain texts in the Essay. I spent a lot of time putting the pieces together in a way that I thought would tell us something about the workings of Locke's mind, and, by extension, about the workings of philosophy. I tried to do something somewhat new in the historiography of philosophy. It's not for me to say whether the book is a success, but I feel ok about it.

Purdue University

47 Tabb, “Response,” 2. 


\section{Bibliography}

Aristotle. "On the Soul." In The Complete Works of Aristotle: The Revised Oxford Translation. 2 vols. Edited by J onathan Barnes. Princeton: Princeton University Press, 1984.

Caston, Victor. "The Spirit and the Letter: Aristotle on Perception." In Metaphysics, Soul, and Ethics in Ancient Thought: Themes from the Work of Richard Sorabji. Edited by Ricardo Salles, 245- 320. Oxford: Clarendon Press, 2005.

Cohen, I. Bernard. Franklin and Newton: An Inquiry into Speculative Newtonian Experimental Science and Franklin's Work in Electricity as an Example Thereof. Philadelphia: The American Philosophical Society, 1956.

Descartes, René. Discourse on Method, Optics, Geometry, and Meteorology. Revised edition, Translated by Paul J . Olscamp. Indianapolis: Hackett Publishing, 2001.

- - - . Oeuvres de Descartes. 11 vols. Edited by Charles Adam and Paul Tannery. Paris: J . Vrin, 1996.

Hatfield, Gary C. and William Epstein. "The Sensory Core and the Medieval Foundations of Early Modern Perceptual Theory." Isis 70 (1979): 375- 78.

J olley, Nicholas. Locke's Touchy Subjects: Materialism and Immortality. Oxford: Oxford University Press, 2015.

Jones, Jan-Erik. “Locke on Real Essence." In Stanford Encyclopedia of Philosophy, revised September 4, 2018. https:// plato.stanford.edu/ entries/real-essence/.

Koyré, Alexandre. "The Significance of the Newtonian Synthesis.” In Newtonian Studies. Chicago: University of Chicago Press, 1965.

Locke, J ohn. The Works of J ohn Locke. 10 vols. London, 1823.

- - - An Essay concerning Human Understanding. Edited by Peter H. Nidditch. Oxford: Clarendon Press, 1975.

---. The Reasonableness of Christianity. Edited by J ohn C. Higgins-Biddle. Oxford: Clarendon Press, 1999.

Malebranche, Nicolas. Oeuvres complètes de Malebranche. 20 vols. Edited by André Robinet. Paris: J . Vrin, 1958- 84.

- - - The Search After Truth with Elucidations of The Search after Truth. Translated by Thomas M. Lennon and Paul J. Olscamp. Cambridge: Cambridge University Press, 1997.

Mill, J ohn Stuart. A System of Logic, Ratiocinativeand Inductive. 2nd ed. 2 vols. London, 1864. 
Pasnau, Robert. 'The Conceivability of Locke's Image of the World: Some Thoughts on J acovides," Locke Studies 19 (2019). https:/ / doi.org/ 10.5206/ ls.2019.8432.

Pringle-Pattison, Seth. In An Essay concerning Human Understanding, by J ohn Locke. Edited by Seth Pringle-Pattison. Oxford: Clarendon Press, 1924.

Tabb, Kathryn. "Response to Locke's Image of the World," Locke Studies 19 (2019). https:// doi.org/ 10.5206/ls.2019.8431.

Wolf-Devine, Celia. "Descartes on Visual Spatial Perception." In Descartes' Natural Philosophy. Edited by Stephen Gaukroger, J ohn Schuster, and J ohn Sutton, 506- 23. New York: Routledge, 2000. 